Magdalena Butrymowicz

(1) https://orcid.org/0000-0002-9920-5860

Uniwersytet Papieski Jana Pawła II w Krakowie

\title{
Tożsamość społeczna mniejszości Ukraińskiej w Polsce -
} rys prawno-socjologiczny

https://doi.org/10.15633/9788374389839.13

Człowiek rodzi się jako wolna istota ludzka z natury swojej społeczna, czyli funkcjonująca w społeczeństwie, dlatego swoją osobność zyskuje pod wpływem społeczeństwa, w którym istnieje, i jego kultury. Ujęcie socjologiczne człowieka postrzega go jako istotę myślącą, która ma za zadnie odkryć, co jest dla człowieka ważne, pożądane i cenne, aby odkryć wartość, którą urzeczywistni i zrealizuje w życiu' ${ }^{1}$. Człowiek funkcjonuje w określonym społeczeństwie, w którym rządzą normy prawne, pewne niepisane zasady, tradycje i zwyczaje. Społeczeństwo zarazem funkcjonuje w ramach państwa. Bardzo często samo państwo wyróżnia i podkreśla istnienie w ramach swojego systemu narodu jako samodzielnie funkcjonującej i świetnie zorganizowanej grupy społecznej. Naród taki jest zazwyczaj grupą dominującą i sprawującą kontrolę nad państwem, a obok narodu istnieją i funkcjonują mniejszości. Zarówno porządek prawny, jak i badania socjologiczne identyfikują te oddzielne grupy, nazywają je i próbują określić ich charakter i relacje do państwa i narodu. Państwo polskie, postrzegane powszechnie jako etnicznie jednolite, wyróżnia istnienie na swoim terytorium dominującj grupy społecznej, jaką jest naród polski, oraz mniejszych grup społecznych, czyli mniejszości etnicznych i narodowych. Prawnie te trzy grupy zostały definiowane, a socjologia stara

1 J. Maciejewski, Grupy dyspozycyjne społeczeństwa polskiego, Wydawnictwo Uniwersytetu Wrocławskiego, 2006, s. 154, 377. 
się określić ich relacje. Niemniej jednak ostatnie lata przyniosły szereg zmian społecznych w tym stabilnym i przewidywalnym uniwersum. Dynamika społeczna i sytuacja polityczna za wschodnią granicą Polski doprowadziły do zwiększonej migracji obywateli Ukrainy do Polski. Dane statystyczne Urzędu Ochrony Konkurencji i Konsumentów wskazują, iż obecnie Ukraińcy stanowią 3,5\% społeczeństwa w Polsce ${ }^{2}$. Doszło zatem do znacznej zmiany w substancji społecznej Polski, gdzie oprócz dominującej grupy społecznej, jaką jest naród polski, zaczyna istnieć druga silna grupa osób deklarujących związek z narodem ukraińskim. Zasadne jest zatem dokonanie analizy o charakterze prawno-socjologicznym tej grupy i podjęcie próby dookreślenia jej struktury i przeanalizowania, czy można jej przypisać posiadanie tożsamości zbiorowej. Człowiek bowiem uczy się i poznaje inną kulturę i interpretuje ją w języku dla niego zrozumiałym. Elementem tego procesu jest zatem wytworzenie tożsamości społecznej, która umiejscawia określonego człowieka czy określoną grupę w relacji do innych jednostek czy społeczeństw funkcjonujących w ramach uporządkowanego i kulturowo integralnego społecznego świata ${ }^{3}$. W pierwszej kolejności należy należy jednak zdefiniować samo społeczeństwo, naród i mniejszości, a następnie w oparciu o te kategorie zbadać grupę docelowa, jaką stanowią osoby przybywające do Polski z Ukrainy.

\section{Człowiek, społeczeństwo, naród i ich tożsamość}

Encyklopedyczna definicja człowieka - istoty żywej, wyróżniającej się najwyższym rozwojem psychiki i życia społecznego ${ }^{4}$ - prowadzi do umiejscowienia człowieka w ramach określonej grupy społecznej, rządzonej według określonej normy prawnej. $\mathrm{Z}$ drugiej jednak strony prawo nie zna

2 Urząd do Spraw Cudzoziemców, Raport na temat obywateli Ukrainy (wg. stanu na dzień 1.07.2019), https://udsc.gov.pl/statystyki/raporty-specjalne/biezaca-sytuacja-dotyczaca-ukrainy/ (24.01.2020).

3 T. Paleczny, Socjologia tożsamości, Kraków 2008, s. 8.

4 Człowiek, Homo sapiens, istota żywa wyróżniająca się wśród innych najwyższym rozwojem psychiki i życia społecznego, jedyna posiadająca kulturę i zdolna do jej tworzenia, pod względem biologicznym gatunek człowiekowatych (Homo sapiens) żyjący od schyłku plejstocenu. Zob. Człowiek, w: Encyklopedia PWN, https://encyklopedia.pwn.pl/haslo/ czlowiek;3889799.html, (7.02.202). 
i nie definiuje człowieka, określa wyłącznie cechy, jakie są przyznane człowiekowi jako istocie ludzkiej, określając początek człowieka od momentu jego urodzenia się jako istoty żywej, urodzonej z kobiety przy udziale mężczyzny, pochodzącej od określonych rodziców ${ }^{5}$. Jednym z podstawowych atrybutów człowieka zatem jest prawo do posiadania własnej tożsamości. Brak jest jednak precyzyjnego określenia, co należy rozumieć pod tym pojęciem, a zatem najprościej ująć ją w formie pytania: kim jestem? - jako tożsamość indywidualna, a kim jesteśmy? - jako tożsamość zbiorowa. Tożsamość określa zatem relacje między jednostkami, a także relacje jednostki do grupy oraz między grupami. Pozostaje rezultatem klasyfikacji świata społecznego, stanowi obraz określonej grupy, zintegrowanego systemu elementów oraz cech, jakie odróżniają jedną grupę od drugiej. Człowiek porusza się bowiem w obrębie jednej znanej mu grupy kulturowej i funkcjonuje w ramach uporządkowanego i wyznaczonego mu przez tożsamość kulturową świata. Tożsamość w tym rozumieniu jest więc całością, symboliczną konstrukcją, dla której nośnikiem i elementem budującym jest kultura ${ }^{6}$.

Emil Durkheim ${ }^{7}$ definiuje społeczeństwo jako zbiór idei, a fakty społeczne są faktami duchowymi. Jednostki, które tworzy społeczeństwo, mają wyjątkową naturę, odrębną od pozostałych jednostek, a każda jednostka ma swoją osobowość, odmienną od pozostałych jednostek funkcjonujących razem z nią w społeczeństwie. Skutkiem połączenia się psychiki jednostek w społeczeństwie powstaje nowa rzeczywistość, już nie jednostkowa, ale zbiorowa. Wyraża się ona wtedy na zewnątrz jako zbiór symboli, znaków, przekonań zbiorowych, co jest określane jako tradycja i kultura. Bowiem jednostki żyją razem, a nie osobno. Istnienie świadomości zbiorowej jest faktem społecznym, a społeczeństwo to przede wszystkim świadomość zbiorowa ${ }^{8}$.

5 Dział I A Rodzice i Dziecko, Rozdział I, Pochodzenie Dziecka, Kodeks Rodzinny i opiekuńczy, Ustawa z dnia 25 lutego 1964 r. (Dz.U. z 20I9, poz. 2086 t. j.).

6 T. Paleczny, Socjologia tożsamości, Kraków 2008, s. 7-9.

7 Emil Durkheim, francuski filozof, socjolog, pedagog, twórca realizmu socjologicznego oraz teorii faktów społecznych. Zob. Émile Durkheim [hasło], w: Encyclopedia Britannica, https://www.britannica.com/biography/Emile-Durkheim (12.01.2020).

8 W. Jacher, Teoria więzi społecznej w socjologii Emila Durkheima, Lublin 1973, s. 54-56. 
Theodore $\mathrm{Abel}^{9}$ i Florian Znaniecki ${ }^{10}$ rozwinęli teorię Emila Durkheima, toworząc model istnienia grupy społecznej określanej humanizmem społecznym. Podstawowym założeniem tego stanowiska było przyjęcie jedności grupy jako fikcji powstałej w umysłach poszczególnych jej członków. Jedność - jak pisze Znaniecki - jest wynikiem wspólnej determinacji tych osób, które chcą przynależeć do takiej grupy i pragną jej jedności. Grupa taka jako całość funkcjonuje jedynie w ich pojęciu, ale skutki tego funkcjonowania widoczne na zewnątrz. To przekonanie, że grupa istnieje, ma wpływ na jej zachowanie i służy za punkt odniesienia. Znaniecki podkreślał także, iż analiza konkretnej grupy społecznej i jej klasyfikacja zależą od wielu czynników - zarówno o charakterze kulturowym, jak i naturalnym. Pierwszym odniesieniem, jakie w jego ocenie powinno być brane pod uwagę, było konkretne terytorium, które dana grupa zajmuje, oraz geograficzne uwarunkowania tego terenu. Na strukturę społeczną i wewnętrzne uwarunkowania takiej grupy ma bowiem wpływ ukształtowanie terenu, warunki środowiskowe, dostępność określonych surowców oraz sąsiedzi tej grupy. Kolejnym czynnikiem determinującym społeczeństwo jest jego wielkość. Ma to bowiem wpływ na strukturę społeczną i polityczną społeczeństwa. Czynnikami różniącymi społeczeństwa są także: język, którym się posługują, kultura słowa pisanego lub ustny przekaz, a także religia. Proponuje on zatem podział na społeczeństwo rozwinięte i prymitywne. Niemniej jednak konkluduje on, iż każde społeczeństwo jest wyjątkowe, niepowtarzalne i należy je postrzegać jako całość. Te relacje, jakie zachodzą pomiędzy indywidualnymi członkami danej społeczności, są zorganizowane w taki sposób, iż tworzą określony system społeczny. Ten system społeczny powstaje głównie wtedy, gdy społeczeństwo składa się z większej liczby członków. Takie rozbudowane społeczeństwo dzieli się wewnętrznie określonymi obowiązkami, jednostka jest zobowiązana do przestrzegania określonych norm i zasad postępowania, które obowiązują wszystkich. Każdy członek takiej społeczności działa zatem w imię dobra

9 Theodore Fred Abel, polskiego pochodzenia socjolog, autor Podstawy teorii socjologiczne. Zob. Theodore Fred Abel papers, 1930-1984, Columbia University Libraries, http://www. columbia.edu/cu/lweb/archival/collections/ldpd_4078375/ (15.02.2020).

10 Florian Znaniecki, polski socjolog i filozof kultury, zajmował się głównie socjologią empiryczną, nawiązując do neokantyzmu i filozofi wartości. Zob. Zaniecki Florian Witold [hasło], w: Encyklopedia PWN, https://encyklopedia.pwn.pl/haslo/Znaniecki-Florian-Witold;4001956.html (15.02.2020). 
wspólnego i na jego rzecz. Tak skonstruowane społeczeństwo tworzy państwo jako byt wspólny, powstały dla dobra wszystkich ${ }^{11}$.

Powstaje zatem pytanie, czy państwo może funkcjonować wyłącznie w oparciu o kilka grup społecznych funkcjonujących w jego ramach, czy wręcz odwrotnie - musi oprzeć się na jednej dominującej grupie społecznej, jaką jest naród. Socjologia i prawo, zajmując się specyfiką więzi narodowej, dążą w ten sposób skonstruowania definicji narodu. Socjologia głównie analizuje świadomość społeczną w zakresie przynależności narodowej. Ernest Renan ${ }^{12}$ postrzegał naród jako bractwo dusz, które tworzą świadomość moralną pobudzającą ludzi do działania. Człowiek nie jest niewolnikiem swojej rasy, języka ani religii, jest powiązany ze wspólnotą duchową, bowiem naród to duchowa rodzina, a nie grupa określona przez kształt ziemi. Naród można inaczej określić jako wspólnotę wolnych ludzi, którzy wyrazili wolę stworzenia lub przynależności do określonego narodu. Naród nie dysponuje żadnym prawem i nie jest zainteresowany władzą i posiadaniem, a wyłącznie istnieniem wspólnego dla wszystkich punktu odniesienia. Według Renana naród istnieje jako efekt codziennego plebiscytu, w czasie którego jednostka potwierdza swoją przynależność do określonego narodu. Definicja narodu jest wobec tego tworzona w procesie eliminacji, to wspólność powstała w procesie sentymentalnego poświęcenia się w imię idei przez tych, którzy byli gotowi taką ofiarę ponieśćc ${ }^{13}$.

Odmienne podejście do definicji narodu zaproponował Bolesław Limanowski ${ }^{14}$, który nazwał naród organizmem społecznym, w którym świadomość oddzielnych rodów podporządkowuje się tym świadomościom, w których i istnieje wyższy ogólny interes zachowania i utrzymania całości. Zatem niezbędną cechą narodu jest świadomość narodowa. Najważniejszym warunkiem istnienia narodu było dla Limanowskiego czucie się

11 F. Zaniecki, Social Relations and Social Roles: The Unfinished Systematic Sociology, San Francisco 1965, s. 10-16, 86, 40, 281-283.

12 Ernest Renan, francuski filozof, historyk, twórca szkoły filozofii krytycznej. Zob. Ernest Renan [hasło], w: Encyclopedia Britannica, https://www.britannica.com/biography/Ernest-Renan (15.02.2020).

13 E. Renan, What is a Nation? Other Political Writings, Columbia University Press 2018, s. $55-83,249-263$.

14 Bolesław Limanowski, działacz socjalistyczny socjolog, historyk. Zob. Bolesław Limanowski, w: Polski Stownik Biograficzny, https://www.ipsb.nina.gov.pl/a/biografia/boleslaw-limanowski (15.02.2020). 
narodem; określone społeczeństwo samo siebie identyfikuje jako naród i postrzega siebie jako naród ${ }^{15}$.

Socjologia zatem zdefiniowała społeczeństwo i naród, który jest jego częścią, w sposób dość konkretny i dający się nawet zastosować w praktyce do określonej grupy społecznej. Wobec powyższego należy zwrócić uwagę na kwestię podejścia prawa do definicji narodu i postrzegania wspólnoty narodowej i społecznej. Konstytucja Rzeczpospolitej Polskiej ${ }^{16}$ posługuje się w swojej treści zamiennie dwoma pojęciami: naród i obywatel. Gdzie naród wyraźnie jest dookreślany jako naród polski. W kilku miejscach w Konstytucji twórcy odróżnili naród ${ }^{17}$ od obywateli. Sama preambuła odnosi się do narodu jako suwerena, aby w dalszej już zasadniczej części skonstatować, iż państwo polskie należy do wszystkich jego obywateli ${ }^{18}$. W art. 4 jednak po raz kolejny ustawodawca nawiązał do narodu jako do suwerena, który sprawuje najwyższą władzę w państwie ${ }^{19}$. Piotr Tuleja w swoim komentarzu do artykułu $4^{20}$ wskazuje, iż jest to rozumienie narodu w sensie politycznym, a nie etnicznym, nawiązując w ten sposób do orzeczenia Trybunału Konstytucyjnego z 2004 roku ${ }^{21}$, który w kontekście wyborów parlamentarnych przyjął definicję narodu jako grupy osób posiadających obywatelstwo polskie. Założenia Tulei pomijają jednak fakt, iż sama Konstytucja nie jest spójna w takim rozumieniu narodu,

15 T. Chynczewska-Hennel, Świadomość narodowa szlachty ukrainskiej i kozaczyzny od schytku XVI do połowy XVII w., Warszawa 1985, s. 10-11.

16 Konstytucja Rzeczypospolitej Polskiej, ustawa z dnia 2 kwietnia 1997 (Dz. U. z 1997 poz. 78 , $\mathrm{Nr} 156 \mathrm{z}$ późn. $\mathrm{zm}$.).

17 „my, Naród Polski - wszyscy obywatele Rzeczypospolitej, zarówno wierzący w Boga będącego źródłem prawdy, sprawiedliwości, dobra i piękna, jak i nie podzielający tej wiary, a te uniwersalne wartości wywodzący z innych źródeł, równi w prawach i w powinnościach wobec dobra wspólnego - Polski...”, Konstytucja Rzeczypospolitej Polskiej, ustawa z dnia 2 kwietnia 1997 (DZ.U. z 1997 poz. 78, Nr 156 z późn. zm.).

18 Art. 1 „Rzeczpospolita Polska jest dobrem wspólnym wszystkich obywateli”, Konstytucja Rzeczypospolitej Polskiej, ustawa z dnia 2 kwietnia 1997 (Dz. U. z 1997 poz. 78, Nr 156 z późn. zm.).

19 Art. 4. „1. Władza zwierzchnia w Rzeczypospolitej Polskiej należy do Narodu. 2. Naród sprawuje władzę przez swoich przedstawicieli lub bezpośrednio...”, Konstytucja Rzeczypospolitej Polskiej, ustawa z dnia 2 kwietnia 1997 (Dz. U. z 1997 poz. 78, Nr 156 z późn. zm.).

20 P. Tuleja, Art. 4., w: Konstytucja Rzeczypospolitej Polskiej. Komentarz [online]. Wolters Kluwer Polska, 2019-11-2o, https://sip.lex.pl/\#/commentary/587806598/604038 (13.02.2020).

21 Postanowienie Trybunału Konstytucyjnego z dnia 8 maja 2004 sygn. K 15/o4, opublikowano: OTK-A 2004/5/52. 
oraz w kwestii jednoznacznego użycia tego terminu, dodatkowo ustawy wydane w oparciu o delegacje konstytucyjną nawiązują do narodu w rozumieniu etnicznym. Również twierdzenie stoi w sprzeczności z faktem, iż osoba ubiegająca się o naturalizację musi wykazać się pochodzeniem polskim lub znajomością historii Polski i języka polskiego. Należy zatem zgodzić się ze stanowiskiem Leszka Garlickiego, który - odnosząc się do treści art. 6 Konstytucji ${ }^{22}$, nawiązującego w ust. 2 do dziedzictwa narodowego - stwierdza iż Konstytucja postrzega naród także w sensie etnicznym, bowiem nie każda osoba identyfikująca się z narodem polskim musi posiadać obywatelstwo polskie ${ }^{23}$. Analizując zagadnienie dalej, należy się zatem w pełni zgodzić się z Pawłem Sarneckim, który twierdzi, iż Konstytucja pojęciem naród, szczególnie w rozumienia art. 4 ust. 1, posługuje się w znaczeniu socjologiczno-politycznym i treści tego pojęcia nie należy wyjaśniać przez przepisy prawa ${ }^{24}$. Takie ujęcie narodu polskiego odpowiada także przywołanej powyżej socjologicznej definicji narodu Znanieckiego czy Renana, w której naród był określany jako bractwo dusz czy świadomość społeczna przynależności do określonej grupy, z którą łączą człowieka określone więzy kulturowo-społeczne.

Naród należy zatem postrzegać jako najwyższego suwerena, byt prawny o charakterze polityczno-etnicznym obejmujący osoby, które mają tą samą świadomość przynależności do określonego społeczeństwa, posługują się tym samym językiem, kultywują te same tradycje i zwyczaje. Podkreślić należy w tym miejscu, iż za takim prawno-socjologicznym ujęciem narodu przemawia Ustawa o Karcie Polaka, ${ }^{25}$ która właśnie w swojej preambule nawiązuje do dyspozycji normy konstytucyjnej i obowiązków, jakie ma państwo Polskie w zakresie ochrony dziedzictwa narodu polskiego

22 Art. 6. „1. Rzeczpospolita Polska stwarza warunki upowszechniania i równego dostępu do dóbr kultury, będącej źródłem tożsamości narodu polskiego, jego trwania i rozwoju. 2. Rzeczpospolita Polska udziela pomocy Polakom zamieszkałym za granicą w zachowaniu ich związków z narodowym dziedzictwem kulturalnym...”, Konstytucja Rzeczypospolitej Polskiej, ustawa z dnia 2 kwietnia 1997 (Dz. U. z 1997 poz. 78, Nr 156 z późn. zm.).

23 K. Działocha, Art. 4. w: Konstytucja Rzeczypospolitej Polskiej. Komentarz. Tom I, wyd. II [online]. Wydawnictwo Sejmowe, 2019-09-30, https://sip.lex.pl/\#/commentary/587734532/531972 (13.02.2020).

24 P. Sarnecki, w: Prawo konstytucyjne RP, red. P. Sarnecki, Warszawa 2004, s. 133-134.

25 Karta Polaka, ustawa z dnia 7 września 2007 roku (DZ. U. z 2019 poz. 1598 t. j.). 
i pomocy Polkom, którzy są członkami narodu polskiego ale nie posiadają obywatelstwa polskiego ${ }^{26}$.

Obok faktu istnienia narodu polskiego Konstytucja identyfikuje istnienie na terytorium Polski mniejszości narodowych i etnicznych. W artykule 35 Konstytucji ustrojodawca zapewnił im szczególną ochronę w zakresie zachowania języka, obyczajów i tradycji ${ }^{27}$. Konstytucja zatem nie tylko usankcjonowała fakt istnienia na terytorium Polski dwóch rodzajów mniejszości, ale także przyznała im określone prawa. Konstytucyjne przepisy w zakresie mniejszości etnicznych doprecyzowane zostały w Ustawie o mniejszościach narodowych i etnicznych oraz o języku regionalnym ${ }^{28}$. Przedmiotowa ustawa zdefiniowała mniejszości narodowe jako grupę obywateli, która spełnia łącznie następujące warunki: jest mniej liczebna niż część ludności Rzeczypospolitej Polskiej, w sposób istotny odróżnia się od pozostałych obywateli językiem, kulturą lub tradycją, dąży do zachowania swojego języka, kultury lub tradycji, ma świadomość własnej historycznej wspólnoty narodowej i jest ukierunkowana na jej wyrażanie i ochronę, utożsamia się z narodem zorganizowanym we własnym państwie, jej przodkowie zamieszkują tereny Rzeczypospolitej od co najmniej stu lat. W dalszej części ustawodawca wymienił enumeratywnie uznane przez niego mniejszości narodowe, do których zalicza się mniejszość np. białoruską, czeską, ukraińską czy litewską ${ }^{29}$.

26 „realizując postanowienia Konstytucji Rzeczypospolitej Polskiej w zakresie udzielania pomocy Polakom zamieszkałym za granicą w zachowaniu ich związków z narodowym dziedzictwem kulturalnym, wypełniając moralny obowiązek wobec Polaków, którzy na skutek zmiennych losów naszej Ojczyzny utracili obywatelstwo polskie, spełniając oczekiwania tych, którzy polskimi obywatelami nigdy wcześniej nie byli, lecz ze względu na swoje poczucie tożsamości narodowej pragną uzyskać potwierdzenie przynależności do Narodu Polskiego, w celu wzmocnienia więzi łączących Polaków z Macierzą oraz wspierając ich starania o zachowanie języka polskiego oraz kultywowanie tradycji narodowe...”, Karta Polaka, ustawa z dnia 7 września 2007 roku (DZ. U. z 2019 poz. 1598 t. j.).

27 Art. 35. „1. Rzeczpospolita Polska zapewnia obywatelom polskim należącym do mniejszości narodowych i etnicznych wolność zachowania i rozwoju własnego języka, zachowania obyczajów i tradycji oraz rozwoju własnej kultury. 2. Mniejszości narodowe i etniczne mają prawo do tworzenia własnych instytucji edukacyjnych, kulturalnych i instytucji służących ochronie tożsamości religijnej oraz do uczestnictwa w rozstrzyganiu spraw dotyczących ich tożsamości kulturowej...” Konstytucja Rzeczypospolitej Polskiej, ustawa z dnia 2 kwietnia 1997 (DZ. U. z 1997 poz. 78, Nr 156 z późn. zm.).

28 Ustawa z dnia 6 stycznia 2005 r. o mniejszościach narodowych i etnicznych oraz o języku regionalnym (Dz. U. z 2017 poz. 823 t. j.).

29 Art. 2 ust. 1, Ustawa z dnia 6 stycznia 2005 r. o mniejszościach narodowych i etnicznych 
Obok mniejszości narodowych ustawa wyróżnia także mniejszości etniczne. Definicja mniejszości etnicznych jest zakresowo zbliżona do definicji mniejszości narodowych. Poprzez mniejszość etniczną rozumie się bowiem mniejszość, która jest liczebnie mniejsza od pozostałej części ludności Rzeczypospolitej Polskiej, w sposób istotny odróżnia się od pozostałych obywateli językiem, kulturą lub tradycją, dąży do zachowania swojego języka, kultury lub tradycji, ma świadomość własnej historycznej wspólnoty etnicznej i dąży do jej ochrony i zewnętrznego wyrażania. Przodkowie powinni zamieszkiwać na terytorium Rzeczypospolitej od conajmniej stu lat, grupa ta nie utożsamia się z narodem, który jest grupą dominującą w państwie, w którym zamieszkuje. Mniejszością etniczną uznaną przez ustawodawcę jest choćby mniejszość karaimska czy łemkowska $^{30}$.

Ustawa przyznaje mniejszościom niezależnie od kwalifikacji szereg uprawnień i praw. Najważniejszym prawem zaś jest wolność jednostki w samookreśleniu przynależności do danej mniejszości, czyli Durkheimowska świadomość przynależności, autonomia plebiscytu i wola wewnętrzna przynależności do danej wspólnoty. Artykuł 4 wskazuje, iż każda osoba, która należy do mniejszości ma prawdo swobody wyboru ${ }^{31}$. Ustawodawca przyznał mniejszościom prawo do samo decydowania o sposobach zachowania własnych tradycji i zwyczajów, a przede wszystkim języka. Niemniej jednak zarazem w ocenie ustawodawcy oprócz ochrony różnorodności etnicznej państwa polskiego zasadna i oczekiwana przez ustawodawcę jest integracja obywatelska i społeczna mniejszości w społeczność polską ${ }^{32}$. Brakuje jednak doprecyzowania, co ustawodawca rozumie pod pojęciem integracji obywatelskiej i społecznej. Ustawowy zakres ochrony należnej mniejszościom zawiera się w obszarach takich jak ochrona języka mniejszości, w tym języka regionalnego, oświata oraz kultura ${ }^{33}$.

oraz o języku regionalnym (Dz. U. z 2017, poz. 823 t.j.).

30 Art. 2 ust. 2, Ustawa z dnia 6 stycznia 2005 r. o mniejszościach narodowych i etnicznych oraz o języku regionalnym (DZ.U. z 2017, poz. 823 t.j.).

31 Art. 4, Ustawa z dnia 6 stycznia 2005 r. o mniejszościach narodowych i etnicznych oraz o języku regionalnym (Dz.U. z 2017, poz. 823 t.j.).

32 Art. 5, Art. 8, art. 18, Ustawa z dnia 6 stycznia 2005 r. o mniejszościach narodowych i etnicznych oraz o języku regionalnym (Dz.U. z 2017, poz. 823 t.j.).

33 Art. 18, Ustawa z dnia 6 stycznia 2005 r. o mniejszościach narodowych i etnicznych oraz 
Większość mniejszości dąży do ochrony swojej niezależności i odmienności, podkreślając swoją tożsamość zbiorową poprzez zintegrowane takie elementy jak: kultywowanie języka, obrzędów religijnych, wydawanie własnych czasopism czy zrzeszanie się w organizacje o zasięgu regionalnym lub ogólnopolskim. Można wskazać na przykład na narodową mniejszość białoruską, która zamieszkuje głównie region województwa podlaskiego. W około czterdziestu siedmiu placówkach oświatowych uczniowie należący do mniejszości białoruskiej uczą się języka białoruskiego. Funkcjonuje również szereg organizacji i stowarzyszeń, głównie młodzieżowych, których zadaniem statutowym jest krzewienie i ochrona tożsamości białoruskiej. Wydawane są również czasopisma o zasięgu ogólnopolskim, propagujące kulturę białoruską, oraz działają niepubliczne media ${ }^{34}$. Kultura mniejszości jest zatem określona i posiada cechy odróżniające ją od innych grup społecznych, a w szczególności od grupy dominującej, jaką jest naród polski. Przyjęcie bowiem - jak chciał Tuleja - rozumienia narodu polskiego jako grupy obywateli, spowoduje uznanie, iż mniejszość narodowa w ogóle w Polsce nie istnieje, bowiem jednym z podstawowych warunków uznania danej grupy za mniejszość narodową jest posiadanie obywatelstwa polskiego. Dochodzi zatem do zatarcia się granicy pomiędzy mniejszościami narodowymi a narodem polskim, bowiem mniejszości narodowe zostają włączone do narodu polskiego. Przyjmując założenie, iż ludzie działają w odniesieniu do świata zgodnie z modelem subiektywnym, okazuje się, że założenie Tulei jest błędne. Traktując bowiem społeczeństwo jako podmiot nadrzędny w stosunku do narodu i mniejszości, które zawierają się w pojęciu społeczności, Tuleja łączy pojęcie narodu ze społeczeństwem. Tymczasem naród z założenia jest tą częścią społeczeństwa, która dominuje i sprawuje kontrolę nad państwem, a obok niego istnieją grupy mające poczucie odmienności, będące zarazem obywatelami. Tożsamość społeczna narodu polskiego jest odmienna od tożsamości mniejszości narodowych, które utożsamiają się z innym narodem i tworzą relację z innymi narodami w oparciu kulturowy sens swojego uniwersum. Norma prawna powinna pozostawać zatem spójna z wynikiem so-

o języku regionalnym (DZ.U. z 2017, poz. 823 t.j.).

Charakterystyka mniejszości narodowych i etnicznych w Polsce, http://mniejszosci.narodowe.mswia.gov.pl/mne/mniejszosci/charakterystyka-mniejs/648o, Charakterystyka-mniejszosci-narodowych-i-etnicznych-w-Polsce.html (14.01.2020). 
cjologicznej analizy społeczeństwa, jego więzi oraz procesów i struktur. Przyjęcie za Sarneckim, iż konstytucyjne rozumienie narodu w sensie socjologiczno-politycznym najlepiej odpowiada rzeczywistości społecznej, bowiem nie eliminuje tożsamości mniejszości narodowych oraz tożsamości narodu polskiego, które także podlegają konstytucyjnej ochronie. Oprócz problemu interpretacji konstytucyjnego rozumienia pojęcia narodu pojawia się także problem wyeliminowania grup o niedookreślonej tożsamości zbiorowej, co jest konsekwencją kompilacji braku jednoznacznej tożsamości indywidualnej i normy prawnej.

W świetle powyższych rozważań można zatem przyjąć, iż faktycznie na terytorium Polski zamieszkuje mniejszość ukraińska czy rosyjska, która może wykazać się faktem posiadania obywatelstwa polskiego i z tego tytułu posiada status mniejszości narodowej. Równolegle w granicach państwa Polskiego zamieszkują obywatele Ukrainy, którzy nie posiadają obywatelstwa polskiego, oraz osoby legitymujące się Kartą Polaka. Historycznie mniejszość ukraińska w Polsce jest konsekwencją podpisania paktu Ribbentrop-Mołotow i wyznaczenia tak zwanej Lini Curzona, która doprowadziła do podziału ziem zamieszkałych przez ludność identyfikującą się z tożsamością ukraińską ${ }^{35}$ pomiędzy państwo Polskie a nowo powstałe republiki radzieckie. Terytorium Polski zamieszkiwała w tym czasie znaczna grupa ludności identyfikującej się z narodem ukraińskim. Przedmiotowego stanu rzeczy nie zmieniła podpisana we wrześniu 1944 roku umowa pomiędzy tymczasowym komunistycznym rządem Polski a rządem Radzieckiej Republiki Ukraińskiej o repatriacji, której konsekwencją były przymusowe przesiedlenia osób pochodzenia ukraińskiego do republik radzieckich. Doszło zatem do podziału tej skonsolidowanej społeczności na dwie grupy, na większość zamieszkującą obecnie na Ukrainie oraz mniejszość zamieszkującą na terenie Polski. Powstał podział tych społeczności, który miał wpływ na ich strukturę wewnętrzną i tożsamość kulturową. Pozostała w Polsce grupa ukraińska podjęła starania o zachowanie ciągłości wartości podstawowych ich kultury oraz tradycji i języka.

35 W tym miejscu należy wskazać, że nie można jednoznacznie uznać, iż była to ludność identyfikującą się z obecnym państwem ukraińskim, bowiem tożsamość zbiorowa państwa ukraińskiego jest dopiero w procesie tworzenia się. Zob. M. Parkasiewicz, Bandera to nie wszystko. Wokót sporu o ukraińską to żsamość, https://klubjagiellonski.pl/2019/11/05/ bandera-to-nie-wszystko-wokol-sporu-o-ukrainska-tozsamosc/ (10.01.2020). 
Tożsamość jest bowiem zawsze tworzona w działaniu, jest dynamiczna i może się rozwijać i działać swobodnie wyłącznie wtedy, gdy cieszy się pełną autonomią. Tymczasem w wyniku Akcji Wisła doszło do zniszczenia tradycyjnych struktur religijnych i kulturowych tej społeczności, która sztucznie została rozmieszczona w różnych częściach państwa polskiego $^{36}$. Mniejszość ta przerwała jednak ten dość trudny okres w swojej historii i w 1956 roku powstało Ukraińskie Towarzystwo Społeczno-Kulturalne, którego kontynuatorem jest obecnie Związek Ukraińców w Polsce, który także pozostaje członkiem Międzynarodowych Struktur Ukraińskich $^{37}$. Obok Związku działa także Towarzystwo Ukraińskie, Ukraińskie Towarzystwo Nauczycielskie w Polsce czy Organizacja Młodzieży Ukraińskiej "PŁAST". Wydawane są liczne czasopisma i dzienniki ukraińskie oraz nadawane są audycje radiowe w języku ukraińskim ${ }^{38}$.

Pewien ugruntowany status quo mniejszości ukraińskiej w Polsce uległ znacznemu zachwianiu w 2012 roku, kiedy rozpoczęła się wzmożona migracja obywateli Ukrainy do Polski. Liczba osób deklarujących pochodzenie ukraińskiego zaczęła gwałtownie rosnąć i zaledwie w ciągu dwóch lat wzrosła z około 38 ooo do 123 ooo i z roku na rok coraz bardziej wrasta$\mathrm{ła}^{39}$. Analizując obecne statystki, wskazać należy, iż w 2019 roku obywatele Ukrainy pozostawali nadal w najliczniejszej grupie obywateli innych państw, którzy złożyli wnioski o przyznanie im ochrony międzynarodowej, a ich liczba kształtuje się na poziomie $12 \%$ wszystkich wniosków. Zaobserwować ponownie można tendencję wzrostową w porównaniu do 2018 roku, kiedy to ogólna liczba wniosków o nadanie statusu uchodźcy wynosiła 11\% wszystkich wniosków. Niemniej jednak ogólna liczna wniosków o udzielenie ochrony międzynarodowej składana przez obywateli Ukrainy znacznie zmalała w 2019 roku i wyniosła 220, gdy rok wcześniej

36 M. Barwiński, Konsekwencje zmian granic iprzeksztatceń politycznych po II Wojnie światowej na liczebność i rozmieszczenie Ukrainców, Łemków, Białorusinów i Litwinów w Polsce, w: Problematyka geopolityczna ziem polskich, red. P. Eberhardt, Warszawa 2008, s. 217219, 222 (Geographical Studies, 218).

37 Informacje o stowarzyszeniu, http://www.zup.ukraina.com.pl/index.php?option=com content\&task $=$ view\&id $=1 \&$ Itemid $=2(14.02 .2020)$.

38 Charakterystyka mniejszości narodowych i etnicznych w Polsce, http://mniejszosci.narodowe.mswia.gov.pl/mne/mniejszosci/charakterystyka-mniejs/648o, Charakterystyka-mniejszosci-narodowych-i-etnicznych-w-Polsce.html (10.02.2020).

M. Jaroszewicz, O. Małynowska, Najnowsza migracja z Ukrainy do Polski: (nie)staty fenomen?, Warszawa 2018, s. 4. 
było to 466 wniosków. W porównaniu z poprzednimi latami zmalała także liczba decyzji szefa Urzędu do spraw cudzoziemców dotyczących obywateli Ukrainy. W 2019 wydano łącznie 141 decyzji w zakresie ochrony międzynarodowej, w tym 85 negatywnych, gdy w 2018 było wydanych 619 decyzji, w tym 443 negatywnych ${ }^{40}$. Badania statystyczne przeprowadzone przez firmę Selectivv, polegające na analizie zachowania posiadaczy smartfonów, wykazały, iż obywatele Ukrainy stanowią, aż 3,5\% mieszkańców Polski, a blisko 12\% obecnie mieszkających osób planuje osiedlić się na stałe w Polsce ${ }^{41}$.

Powyższe dane pozwalają zatem stwierdzić, iż na terenie Polski zamieszkuje dawna mniejszość ukraińska powstała w wyniku historycznych podziałów granic, która posiada już zorganizowaną strukturę ochrony własnej tożsamości kulturowej, identyfikującą się zarazem z państwem polskim jako państwem pochodzenia. Obok tej społeczności funkcjonuje obecnie nowa napływowa ludność, która mocniej identyfikuje się z państwem ukraińskim, co jest manifestowane w najróżniejszy sposób, jak choćby przypinanie na ubraniach roboczych flag ukraińskich obok loga firmy czy oznaczania maszyn lub szafek w pracy flagami Ukrainy ${ }^{42}$. Osiedlają się także w innych częściach Polski, główne skupiska mniejszości ukraińskiej są obecnie na terenie województwa mazowieckiego, zachodniopomorskiego czy małopolskiego. W Łodzi ${ }^{43}$ i Krakowie ${ }^{44}$ powstały klasy uczące języka, historii i kultury ukraińskiej. Grupa ta nie jest jednak tożsamościowo spójna, bowiem znaczna część migrantów to osoby deklarujące przynależność do narodu polskiego. Szacowana ogólna liczba

40 Urząd do Spraw Cudzoziemców, Raport na temat obywateli Ukrainy (wg. stanu na dzień 01.07.2019), https://udsc.gov.pl/statystyki/raporty-specjalne/biezaca-sytuacja-dotyczaca-ukrainy/ (24.01.2020).

41 S. Czubkowska, Smartfony policzyly Ukraińców. Ile Ukrainek planuje mieć dzieci?, „Gazeta Wyborcza" (7.03.2019), https://wyborcza.pl/7,156282,24522397,smartfony-policzyly-ukraincow-ile-ukrainek-planuje-miec-dzieci.html?fbclid=IwAR3 CmUtV176y IeLpxOd56koD11d UIvkWNp2rignJzcuKWQdS3ea-owgZndA (07.02.2020).

42 Źródło: badania własne.

43 A. Zboińska, Łódzkie liceum otwiera klasę ukraińska. Będa zajęcia m.in. z kulturologii ukrainskiej, „Dziennik Łódzki” (16.03.2019), https://dzienniklodzki.pl/lodzkie-liceum-otwiera-klase-ukrainska-beda-zajecia-min-z-kulturologii-ukrainskiej-zdjecia/ar/13968686 (14.02.2020).

44 M. Kursa, W Krakowiepowstana dwujęzyczne, polsko-ukraińskie klasy, „Gazeta Wyborcza” (17.06.2017), https://krakow.wyborcza.pl/krakow/7,44425,21970014,w-krakowie-powstana-dwujezyczne-polsko-ukrainskie-klasy.html?disableRedirects=true (13.02.2020). 
nowo przybyłych Ukrainców do Polski wynosi około dwóch milionów, a prawie milion $\mathrm{z}$ nich legitymuje się posiadaniem Karty Polaka ${ }^{45}$. Przesłanki wydania Karty Polaka określa ustawa, wskazując, iż może ją otrzymać wyłącznie osoba, która deklaruje przynależność do narodu polskiego i może wykazać się polskim pochodzeniem. Dokument ten potwierdza przynależność do narodu polskiego i jest zarezerwowany wyłącznie dla osób deklarujących pochodzenie od osób objętych wspomnianymi powyżej umowami repatriacyjnymi ${ }^{46}$. Ustawodawca polski zakłada zatem pełną asymilację osób posiadających Kartę Polaka i nie traktuje ich jak osoby przynależące do mniejszości. Założeniem pozostaje zablokowanie możliwości kultywowania odmiennej tożsamości zbiorowej i integracja z narodem polskim. W zamian osoby te otrzymują specjalny pakiet socjalny i złagodzenie formalności prawo-administracyjnych w osiedleniu się w Polsce. Osoba, która pragnie otrzymać Kartę Polaka, obowiązana jest złożyć formalną deklaracje przynależności do narodu polskiego, wykazać się znajomością języka polskiego, który musi być uznawany przez nią za ojczysty, musi wykazać się znajomością i kultywować polskie tradycje i zwyczaje, dodatkowo musi udowodnić pochodzenie od rodziców lub dziadków narodowości polskiej ${ }^{47}$. Przekładając te wymogi na grunt przywołanych definicji narodu i mniejszości, stwierdzić należy, iż taka osoba w chwili otrzymania Karty Polaka zostaje włączona formalnie do narodu polskiego, a nie staje się członkiem mniejszości ukraińskiej w Polsce. Ustawodawca polski domaga się bowiem deklaracji tożsamości polskości i wyeliminowania różnic pochodzenia i odmiennej tożsamości kulturowej. Migrant przekraczający granicę Polski z Kartą Polaka staje się zatem członkiem narodu polskiego, w jakim rozumie go Konstytucja, a z chwilą otrzymania obywatelstwa nabywa pełnię praw politycznych. Zostaje włączony to tożsamości zbiorowej narodu polskiego w oparciu o normę prawną. Powyższa charakterystyka prawno-socjologiczna mniejszości ukraińskiej w Polsce, pozwala zatem stwierdzić, iż ponad połowa osób

45 Z. Bartuś, Ukraincy zostana Polakami. Ilu? Milion, dwa miliony? Wszystko zależy od sytuacji na Wschodzie oraz polityki polskiego rządu i samorządów, „Dziennik Polski” (21.05.2019), https://dziennikpolski24.pl/ukraincy-zostana-polakami-ilu-milion-dwa-miliony-wszystko-zalezy-od-sytuacji-na-wschodzie-oraz-polityki-polskiego-rzadu-i/ar/c3-14145441 (19.12.2019).

46 Art. 2, art. 3, Karta Polaka, ustawa z dnia 7 września 2007 roku (Dz. U. z 2019 poz. 1598 t. j.).

47 Art. 2 ust. 1, Karta Polaka, ustawa z dnia 7 września 2007 roku (Dz. U. z 2019 poz. 1598 t.j.). 
przybyłych i osiadłych na terenie Polski to nie osoby zasilające ukonstytuowaną mniejszość ukraińską, a powracający do Polski potomkowie narodu polskiego. Należy zatem uznać, iż mniejszość ukraińską w Polsce po 2012 roku ukonstytuowały trzy rodzaje różnej tożsamości zbiorowej: mniejszości tradycyjnie obecnej na zmianach polskich w wyniku zmian granic w 1944 roku, która zintegrowała się z narodem polskim, osoby deklarujących silny związek z państwem ukraińskim i utożsamiające się kulturowo i społecznie $z$ narodem i państwem ukraińskim oraz posiadacze Karty Polaka. Pod względem prawnym dochodzi jeszcze do wewnętrznego podziału wewnątrz drugiej grupy, bowiem ustawa o mniejszościach przyznaje taki status wyłącznie grupie osób, które posiadają obywatelstwo polskie, większość migrantów nie jest w stanie wykazać się posiadaniem obywatelstwa polskiego. Najbardziej złożona jest tożsamość grupy legitymującej się Kartą Polaka. Osoby te łączą w sobie bowiem elementy kultury polskiej i kultury ukraińskiej. Grupa znajduje się zatem w procesie budowania własnej tożsamości lub zostanie wchłonięta przez naród polski lub mniejszość ukraińską.

Tożsamość społeczna czy tożsamość kulturowa społeczeństwa pozostaje wypadkową dziedzictwa kulturowego i nie ma związku z pochodzeniem danej osoby. Tożsamość społeczna to bowiem zachowanie ciągłości wartości, ich hierarchii, a także ich źródeł i treści systemów sankcjonujących całokszałt uniwersum ${ }^{48}$. Tradycyjna mniejszość ukraińska w Polsce, deklarując przynależność do narodu ukraińskiego, skutecznie obroniła swoją tożsamość zbiorową, czego wyrazem są skutecznie działające organizacje ukraińskie w Polsce. Nowo przybyli migranci także dążą do poszanowania ich odmienności i kultywują swoją tożsamość zbiorową, którą manifestują na każdym kroku. Problemem pozostaje odniesie się do zawieszonej pomiędzy dwoma narodowymi społeczności migrantów, legitymujących się posiadaniem Karty Polaka, gdzie prawo, a nie woluntarystyczny wybór jednostki określiło jej tożsamość i przynależność społeczną.

48 R. Szwed, Tożsamość a obcość kulturowa: studium empiryczne na temat związków pomiędzy tożsamościa społeczno-kulturalna a stosunkiem do obcych, Lublin 2003, s. 59-62. 


\section{Abstrakt}

Tożsamość społeczna mniejszości Ukraińskiej $w$ Polsce - rys prawno-socjologiczny

Dynamika społeczna i sytuacja polityczna za wschodnią granicą Polski doprowadziły do zwiększonej migracji obywateli Ukrainy do Polski. Z danych statystycznych Urzędu Ochrony Konkurencji i Konsumentów wynika, że obecnie Ukraińcy stanowią 3,5\% ludności Polski. Nastąpiła więc znacząca zmiana w substancji społecznej Polski, gdzie obok dominującej grupy społecznej, jaką jest naród polski, istnieje druga silna grupa osób deklarujących związek z narodem ukraińskim. Zasadne jest zatem dokonanie analizy prawnej i socjologicznej tej grupy i podjęcie przynajmniej ogólnej próby sprecyzowania jej struktury i przeanalizowania, czy można jej przypisać posiadanie tożsamości zbiorowej. Człowiek uczy się i poznaje inną kulturę oraz interpretuje ją w zrozumiałym dla siebie języku. Elementem tego procesu jest zatem tworzenie tożsamości społecznej, która sytuuje konkretną osobę, konkretną grupę w stosunku do innych jednostek lub społeczeństw funkcjonujących w uporządkowanym i kulturowo integralnym świecie społecznym. Najpierw jednak należy zdefiniować samo społeczeństwo, naród i mniejszości, a następnie przeanalizować istnienie ich relacji i funkcjonowania.

Słowa kluczowe: prawo, prawa człowieka, prawo do tożsamości

\section{Abstract}

The social identity of the Ukrainian minority in Poland - a legal and sociological outline

The social dynamics and political situation behind the eastern border of Poland led to increased migration of Ukrainian citizens to Poland. Statistical data of the Office of Competition and Consumer Protection indicate that currently Ukrainians constitute $3.5 \%$ of the Polish population. There has therefore been a significant change in the social substance of Poland, 
where in addition to the dominant social group which is the Polish Nation, there is a second strong group of people declaring a relationship with the Ukrainian Nation. It is therefore reasonable to make a legal and sociological analysis of this group and make at least a general attempt to specify its structure and analyse whether it can be attributed to having a collective identity. Man learns and gets to know another culture and interprets it in a language he understands. An element of this process is, therefore, the creation of a social identity that places a specific person, a specific group in relation to other individuals or societies functioning within an ordered and culturally integral social world. First, however, we must define the society itself, the nation and the minorities, and then analyse whether the existence or not of their mutual relations and functioning.

Keywords: law, human rights, right to an identity

\section{Bibliografia}

Bartuś Z., Ukraińcy zostana Polakami. Ilu? Milion, dwa miliony? Wszystko zależy od sytuacji na Wschodzie oraz polityki polskiego rządu i samorządów, „Dziennik Polski” (21.05.2019), https://dziennikpolski24.pl/ukraincy-zostana-polakami-ilu-milion-dwa-miliony-wszystko-zalezy-od-sytuacji-na-wschodzie-oraz-polityki-polskiego-rzadu-i/ar/c3-14145441 (19.12.2019).

Barwiński M., Konsekwencje zmian granic i przeksztatceń politycznych po II wojnie światowej na liczebność i rozmieszczenie Ukrainców, Łemków, Białorusinów i Litwinów $w$ Polsce, w: Problematyka geopolityczna ziem polskich, red. P. Eberhardt, Warszawa 2008, s. 217-219, 222 (Geographical Studies, 218).

Bolestaw Limanowski [hasło], w: Polski stownik biograficzny, https://www. ipsb.nina.gov.pl/a/biografia/boleslaw-limanowski (15.02.2020).

Charakterystyka mniejszości narodowych i etnicznych w Polsce, http://mniejszosci.narodowe.mswia.gov.pl/mne/mniejszosci/charakterystyka-mniejs/648o, Charakterystyka-mniejszosci-narodowych-i-etnicznych-w-Polsce.html (14.01.2020).

Chynczewska-Hennel T., Świadomość narodowa szlachty ukrainskiej i kozaczyzny od schytku XVI do połowy XVII w., Warszawa 1985. 
Człowiek [hasło], w: Encyklopedia PWN, https:/encyklopedia.pwn.pl/haslo/ czlowiek;3889799.html, (7.02.2020).

Czubkowska S., Smartfony policzyty Ukrainców. Ile Ukrainek planuje mieć dzieci?, „Gazeta Wyborcza”, (7.03.2019), https://wyborcza.pl/7,156282,24522397,smartfony-policzyly-ukraincow-ile-ukrainek-planuje-miec-dzieci.html?fbclid=IwAR3CmUtV176y IeLpxOd5 6koD11duivkwnp2rignJzcuKwQdS3ea-owgzndA (7.02.2020).

Działocha K., Art. 4 Konstytucja Rzeczypospolitej Polskiej. Komentarz, Tom I, wyd. II [online], Wydawnictwo Sejmowe, 2019-09-30, https://sip.lex.pl/\#/ commentary/587734532/531972 (13.02.2020).

Émile Durkheim [hasło], w: Encyclopedia Britannica, https://www.britannica.com/biography/Emile-Durkheim (12.01.2020).

Ernest Renan [hasło], w: Encyclopedia Britannica, https://www.britannica. com/biography/Ernest-Renan, (15.02.2020).

Informacje o stowarzyszeniu, http://www.zup.ukraina.com.pl/index. php?option=com_content\&task=view\&id=1\&Itemid=2 (14.02.2020).

Jacher W., Teoria więzi społecznej w socjologii Emila Durkheima, Lublin 1973. Jaroszewicz M., Małynowska O., Najnowsza migracja z Ukrainy do Polski: (nie)staty fenomen?, Warszawa 2018, s. 4.

Kursa M., W Krakowie powstana dwujęzyczne, polsko-ukrainskie klasy, „Gazeta Wyborcza”(17.06.2017), https://krakow.wyborcza.pl/ krakow/7,44425,21970014,w-krakowie-powstana-dwujezyczne-polsko-ukrainskie-klasy.html?disableRedirects=true (13.02.2020).

Maciejewski J., Grupy dyspozycyjne społeczeństwa polskiego, Wydawnictwo Uniwersytetu Wrocławskiego, Wrocław 2006.

Paleczny T., Socjologia tożsamości, Kraków 2008.

Parkasiewicz M., Bandera to nie wszystko. Wokót sporu o ukrainska tożsamość, https://klubjagiellonski.pl/2019/11/o5/bandera-to-nie-wszystko-wokol-sporu-o-ukrainska-tozsamosc/ (10.01.2020).

Renan E., What is a Nation? Other Political Writings, Columbia University Press 2018.

Sarnecki P., w: Prawo konstytucyjne RP, red. P. Sarnecki, Warszawa 2004, s. $133-134$

Szwed R., Tożsamość a obcość kulturowa: studium empiryczne na temat związków pomiędzy tożsamością społeczno-kulturalna a stosunkiem do obcych, Lublin 2003. 
Theodore Fred Abel papers, 1930-1984, Columbia University Libraries, http://www.columbia.edu/cu/lweb/archival/collections/ldpd_4078375/ (15.02.2020).

Tuleja P., Art. 4, Konstytucja Rzeczypospolitej Polskiej. Komentarz [online]. Wolters Kluwer Polska, 2019-11-20, https://sip.lex.pl/\#/commentary/587806598/604038 (13.02.2020).

Urząd do Spraw Cudzoziemców, Raport na temat obywateli Ukrainy (wg stanu na dzień 01.07.2019), https://udsc.gov.pl/statystyki/raporty-specjalne/ biezaca-sytuacja-dotyczaca-ukrainy/, dostęp: 24.01.2020.

Zaniecki Florian Witold [hasło], w: Encyklopedia PWN, https://encyklopedia.pwn.pl/haslo/Znaniecki-Florian-Witold;4001956.html (15.02.2020).

Zaniecki F., Social Relations and Social Roles: The Unfinished Systematic Sociology, San Francisco 1965.

Zboińska A., Łódzkie liceum otwiera klasę ukraińską. Będa zajęcia m.in. z kulturologii ukraińskiej, „Dziennik Łódzki” (16.03.2019), https://dzienniklodzki.pl/lodzkie-liceum-otwiera-klase-ukrainska-beda-zajecia-min-z-kulturologii-ukrainskiej-zdjecia/ar/13968686 (14.02.2020).

\section{Akty prawne i orzeczenia}

Karta Polaka, ustawa z dnia 7 września 2007 roku (Dz.U. z 2019 poz. 1598 t. j.). Kodeks Rodzinny i opiekuńczy, Ustawa z dnia 25 lutego 1964 r. (Dz.U. z 2019 poz. 2086 t.j.).

Konstytucja Rzeczypospolitej Polskiej, ustawa z dnia 2 kwietnia 1997 (Dz.U. z 1997 poz. 78, Nr 156 z późn. zm.).

Postanowienie Trybunału Konstytucyjnego z dnia 8 maja 2004 sygn. K 15/o4, opublikowano: OTK-A 2004/5/52.

Ustawa z dnia 6 stycznia 2005 r. o mniejszościach narodowych i etnicznych oraz o języku regionalnym, (Dz.U. z 2017 poz. 823 t. j.). 